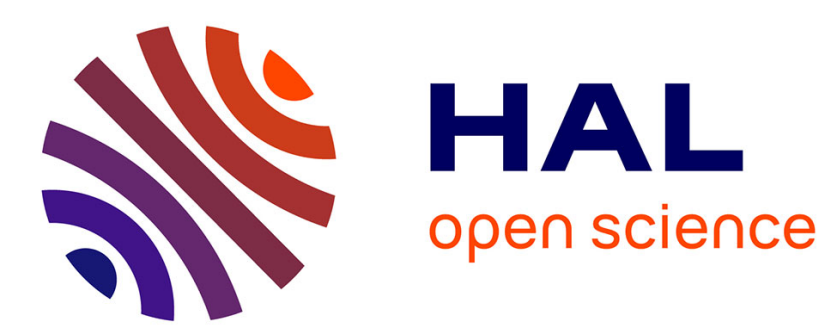

\title{
Measurement and Practices of Social and Racial Segmentation in Cali A Survey of African Colombian Households
}

Olivier Barbary

\section{To cite this version:}

Olivier Barbary. Measurement and Practices of Social and Racial Segmentation in Cali A Survey of African Colombian Households. Population-E, 2002, 57. hal-02477823

\section{HAL Id: hal-02477823 \\ https://hal.science/hal-02477823}

Submitted on 13 Feb 2020

HAL is a multi-disciplinary open access archive for the deposit and dissemination of scientific research documents, whether they are published or not. The documents may come from teaching and research institutions in France or abroad, or from public or private research centers.
L'archive ouverte pluridisciplinaire HAL, est destinée au dépôt et à la diffusion de documents scientifiques de niveau recherche, publiés ou non, émanant des établissements d'enseignement et de recherche français ou étrangers, des laboratoires publics ou privés. 


\title{
Measurement and Practices of Social and Racial Segmentation in Cali
}

\author{
A Survey of African Colombian Households
}

\author{
Olivier BARBARY*
}

\begin{abstract}
Should cultural diversity based on ethnic or geographical origins within one population be accepted, or even encouraged? For "integrationists" the answer is no, in the interest of preserving national unity; for "communalists" the answer is yes, because they refuse to ignore the diversity of identity and of historical experience. Political leaders in Colombia have chosen the second response. However, the implementation of policies adapted to the mechanisms of segregation and discrimination at work in society requires reliable information about the various groups involved. Here, Olivier BARBARY examines the difficulties of estimating the population of African descent in the city of Cali (2 million people). He begins by questioning the scientific and political relevance of such categorization, and emphasizes the importance of relating it to socio-economic and migration data.
\end{abstract}

Colombia has the second highest concentration of blacks in its population for Latin America - behind Brazil and on a par with Venezuela. Despite its demographic importance - about $18 \%$ of Colombia's total population, or nearly 8 million people, according to recent statistical sources - and contrary to a long-standing tradition in the United States, Brazil and the Caribbean, the country's African-origin population has been the subject of little social and demographic research. However, the major political and legal changes associated with adoption of the country's new constitution in 1991 have fuelled a public debate over ethnic minorities in Colombia, focusing on recognition of society as multi-ethnic and, through the concrete legal measures embodied in Law 70, on the institutionalization of multiculturalism as a foundation of citizenship. In common with other Latin American countries, Colombia is trying to redefine the place of

*Institut de Recherche pour le Développement, Centre d'Analyse et de Mathématique Sociales, EHESS, Marseille.

Translated by Mireille Rabenoro. 
its indigenous and African American populations in national society. In this context, the case of the population of African origin raises a number of problems. First, the "historic invisibility" of Colombia's black population, against which the pioneers of African Colombian studies and their successors reacted (see several studies by De Friedemann and Arocha), was replaced by a research output that until very recently was marked by nativist, ruralist and culturalist currents. This approach, though it can be seen to have influenced the lawmakers' choices, provides an inadequate basis for understanding the range of current issues. Second, the question of the social condition of that population, still marked by the legacy of slavery during the colonial and later the republican period (territorial exclusion, social, economic and political marginalization), now has to be addressed in a "globalized" framework that presents contradictions of its own. Economic globalization, strongly favoured by international organizations (the World Bank, the OAS, the IADB, bilateral co-operation, etc.), but also decentralization - or even regionalism - and ethnic identity and environmental protection are the main themes in the debate. The evolution of the law, however, is also an answer to the social and political movement that emerged in Colombia in the late 1980s, building on the specific conditions and identities of black and Indian people. The questions addressed in this article, though they take particular form in Colombia, are thus of general significance.

The issues raised by "the black question" in Colombia are situated mainly at the regional and local levels. Administrative and budgetary decentralization was initiated in 1986 with the direct election of regional governors and mayors, and continued with the implementation of the 1991 Constitution. Elected officials and civil servants in charge of running the administration have expressed a strong demand for information on this topic. At the lower geographic level, the JAL (Juntas de acción local) and neighbourhood associations in the urban districts are also deeply involved. Lastly, although Law 70 is vague about the economic and social consequences of state recognition of the "black communities", particularly the urban ones (Arocha, 1992), it nonetheless legitimates as political actors a series of social movements that have originated in the black population to promote specific claims (Agudelo, 1998; Agier and Hoffmann, 1999). For these new actors in the political arena, access to demographic, geographic and sociological information and its effective use in shaping the debate, are crucially important.

The survey on "Mobility, Urbanization, and Identities of African Colombian Populations" conducted in Cali during April and May 1998 as part of a cooperative programme between CIDSE and IRD(1) sought to

(1) CIDSE : Social and Economic Research and Documentation Centre of Del Valle University in Cali. IRD: Institut de Recherche pour le Développement. The team in charge of designing and conducting the survey included F. Urrea, H.F. Ramirez and A. Estacio for CIDSE, and O. Barbary and S. Bruyneel for IRD. O. Barbary was in charge of survey coordination and V. Robayo of logistics. 
respond to the demand for information through the observation of the demographic, socio-economic and cultural situation of these populations. Among the determinants of their spatial and temporal evolution, priority was given to the ethnic factor for a diagnosis of social and racial segregation in the city, equality of opportunity and discrimination processes. In a first stage, it was necessary to define from both theoretical and methodological perspectives the observational and analytical categories employed. These questions are addressed in the first part of the article, where we take position in the debate over the use of ethnic categories in survey research, illustrating the point with results from the census in Cali. Next, we explain how these concepts were operationalized in the survey. The second part presents and discusses some of the early results, first concerning the size, racial mixture, migration, social and spatial segregation of African Colombian populations in Cali, and their perceptions of discrimination. Logistic models are used to compare the forms and determinants of the assertion of a "black identity" as revealed through self-reported questions in the 1993 census and the CIDSE/IRD survey of 1998.

\section{Why and how to capture the ethnic origin of the population of Cali?}

The majority of the population of the Pacific region of Colombia is black. Since the late 1970s, rural emigration to the coastal towns (Tumaco, Buenaventura) and particularly to Cali has accelerated. The regional metropolis (Figure 1) has become the country's largest concentration of African Colombian population (Urrea, 1997, p. 115) and, through the concentration of migrants from the Pacific region in the working-class neighbourhood of Agua Blanca, has acquired the image of a "black city".

According to the 1993 census, Cali had around 116,000 migrants from municipios $^{(2)}$ with a predominantly black population ${ }^{(3)}$, representing $7 \%$ of the total population and $15 \%$ of all migrants. A rough estimate based on the birthplaces of the parents of individuals born in Cali puts the African Colombian population resident of Cali at the time of the census at $10.5 \%$ of the total (175,000 people). In fact, however, our May 1998 survey estimated the population of African Colombian households at about $27.5 \%$ of the total, or over 540,000 people. This shows the scale of the phenomenon, and also its invisibility in Colombian statistics. Generally speaking, the existing sources are inadequate for analysing the socio-

\footnotetext{
(2) The municipio is the basic administrative unit in Colombia; its area is usually larger than that of the French "commune".

(3) This territorial grouping that we call the "African Colombian population zone" includes the Pacific coast of the Valle del Cauca, Cauca and Nariño departamentos, the whole of the Chocó departamento, as well as seven municipios in the northern part of the Cauca departamento (see Barbary and Ramirez, 1997).
} 


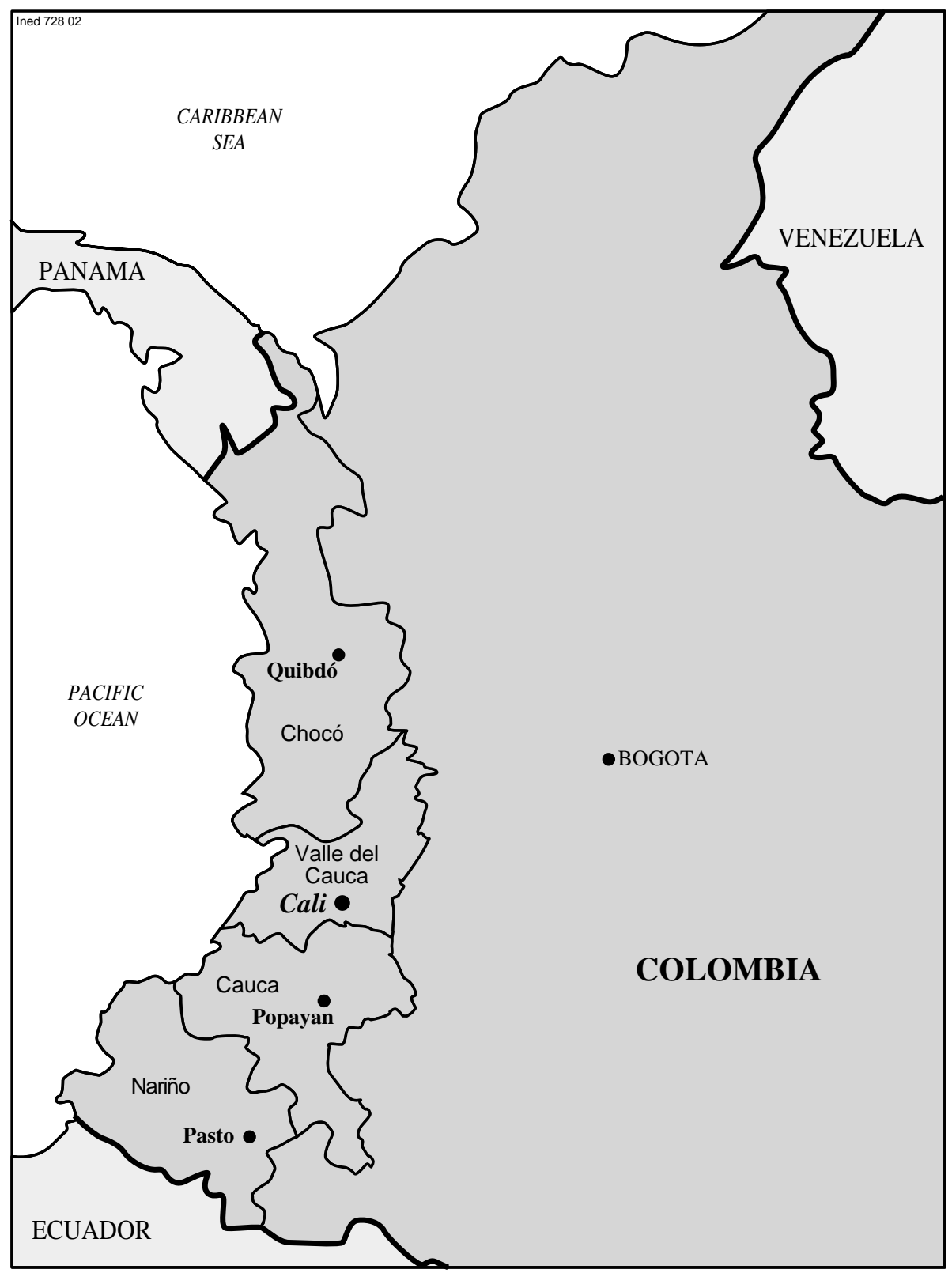

Figure 1.- Cali and the Pacific regions of Colombia 
economic and cultural differentials resulting from the mobility and integration processes specific to the city's different populations, let alone for studying their dynamics. Yet in a context marked by culturalist stereotypes, political rhetoric inspired by the strategies of patronage, and the instant sociology of the media, there is an urgent need for accurate, consistent and detailed information on the living conditions and the socioeconomic and cultural characteristics of this "minority", and all the more so where its demographic importance and migration dynamics make it an essential actor in regional development.

\section{Ethnicity: a user's guide}

In 1997, P. Simon wrote that "the realization and representation of social relations along ethnic lines is one of the outstanding facts of recent decades". But while ethnicity has indeed become a widely used analytical category in the social sciences, there is little agreement on the theoretical and methodological tools required for its use ${ }^{(4)}$. In Colombia, where the headlines are dominated by the themes of armed conflict and drugs, the "ethnic issue" and its corollaries - integration/segregation, equal opportunities, and racism - are less prominent in political and academic discourse than they are in the United States or Europe. Here as elsewhere, however, the public debate is highly confused and usually draws on information that is either incomplete or lacking any statistical basis.

The ethnic minorities of Colombia - unlike those of Mexico or Central America but like those of Brazil - cannot be identified (nor identify themselves) by any linguistic marker. The definition and legitimacy of ethnic, regional and cultural categories as tools for observation and analysis of the differential conditions of social and economic insertion are especially controversial given that these categories are often rendered inoperative by the level of $\mathrm{ra}$ mixing in Colombia. The fact remains that skin colour and physical 7 acteristics (which we will refer to as the phenotype) or certain cultural traits - whether claimed, accepted or imposed-determine social positions and relations. The "ethnic" or "racial" identities, as hybrid products of cultural, social and political constructions, are central to the processes of interaction, symbiosis or confrontation between the various social actors.

The survey conducted in Cali sought to establish a statistical characterization of the actors in these processes, and in particular those now referred to in Colombia as the "African Colombian population". A (minority) section of this population defines itself on an ethnic basis, but

(4) In France, the collection and analysis, particularly by the official statistical apparatus, of data on ethnic affiliation and its supposed effects, is an issue that produces contradictory ethical, ideological and methodological positions, as shown by the lively debate over INED's MGIS (Geographic Mobility and Social Insertion) survey (see Tribalat, 1996; Blum, 1998; Le Bras, 1998; Simon, 1999). 
usually it is non-African Colombians who give it this collective definition (in fact, as we shall see, based on a racial categorization). Be that as it may, most of this population lives in distinct and difficult economic and social circumstances. This is the reason we have applied a phenotypic rather than ethnic characterization to the individuals. This does not mean that we consider race to be a biological or cultural reality, but is simply a recognition that in many social contexts, semantic constructions built around phenotypes are responsible for the kinds of division, hierarchy and segregation that our observation categories are supposed to explain. Our aim is thus to use the categories that are articulated and experienced in everyday life as tools for the scientific observation of a segregated social order. In other words, to produce a diagnosis of the present state of the black question in Cali, and to counter both racist and culturalist stereotypes, we decided that the only coherent approach was by phenotypic characterization, since it is the only one that coincides with the commonly used racial categories, whose social effects we are investigating.

\section{The heuristic failure of ethnic self-identification among urban populations in the 1993 census}

For the first time since racial characterization of the population was abandoned after the 1918 census, and following a lively internal debate, DANE(5) inserted an ethnic question in the 1993 census. This produced high expectations among the leaders of native and African Colombian communities and among researchers. But the results of the question, as regards urban populations, were a disappointment.

For instance, in the whole population of Cali, the individuals answering that they "belong to an ethnic group, an indigenous group or a black community" represented only $0.5 \%$ of the people enumerated (nationally, the proportion is $3.3 \%$ ), while $95.5 \%$ gave a negative answer, and $4 \%$ declined to respond. Even more curiously, among the individuals enumerated in Cali who were born in the regions where the majority of the population is black and mulatto (the Pacific fringe and the northern part of the Cauca) or native and Eed-race (the Andean part of the Cauca and the Nariño), "yes" answ $D$ were again a small minority. The maximum reached among the natives of the Chocó region, where virtually the entire population is of African descent, is only $2.6 \%$.

Many sources have criticized these figures as unrealistic; but they should not come as a surprise. Operationalizing a concept as multifaceted and vague as ethnic affiliation in a census questionnaire administered by hastily trained interviewers(6) for use on a heterogeneous, mixed-race Bureau.

(5) División Administrativa Nacional de Estadística, the Colombian National Statistics

\footnotetext{
(6) In Colombia census questionnaires are not self-administered.
} 
population, was a considerable challenge. The actual word "ethnic" used in the wording of the question is not common in Colombia, and was misunderstood by some respondents. As for the phrase "black community", the political context in 1993 gave it a militant connotation that was at odds with the spirit of the question. The real reasons for these results, however, are not methodological but historical and sociological. Unlike the United States or South Africa, Colombia experienced no institutionalized racial segregation following the abolition of slavery, and the country has no ethnic and political movements comparable to those for civil rights in the United States or against apartheid in South Africa. In the latter countries, segregation, whether a legacy from the past or the product of present issues, including that associated with affirmative action, marks a deep division of society in the political, legal and social spheres(7), as well as in collective consciousness. No comparable institutionalization of ethnic differences has ever existed in Colombia.

Although a sense of ethnic affiliation, shared and spontaneously reported by significant population groups, is not observed in contemporary Colombia at the national level or in the main cities, a very different situation prevails in the Pacific region. There, a rate of $44 \%$ "yes" answers was recorded in the census, with strong local variations whose historical, geographical, economic and social determinants are examined below. For Cali, meanwhile, the census figures do not signify that social and racial discrimination is inexistent, or that only a small number of people are victims of "black" or "Indian" stigmatization. But to demonstrate this, a population classification different from that of the census must be used.

\section{Observing an ethnic minority in Cali: African Colombian households and control households}

From the point of view of measurement, the CIDSE/IRD survey had two major objectives. First, to reveal the behaviour, whether differentiated or not, of the African Colombian population, thus necessitating inclusion in the study of the non-African Colombian population; second, to capture the internal economic, social and cultural heterogeneity of that population, thus implying a diversification in spatial and socio-economic terms of the urban contexts being studied.

The main unit of analysis is the household, and the survey sample therefore included two sub-samples of households, selected in two separate populations, to which the same questionnaire was administered (a total of 1,880 households were interviewed).

- African Colombian households (1,504 households interviewed): households in which, in the interviewer's opinion, at least one person in

(7) As P. Simon has analysed for the United States, this context is reflected in the use for census purposes of ethnic classifications that "work" (Simon, 1997, pp. 14-21). 
the main family nucleus, i.e. the head of the household (h.h.), his or her spouse, or one of the children of the h.h. or of his or her spouse, has black or mulatto phenotypic traits. Consequently, the presence of African Colombian individuals with distant or no blood relationship with the h.h. does not identify the household as African Colombian.

- Non-African Colombian households (376 households interviewed as a control group): these are households in which none of the h.h.'s family nucleus has any black or mulatto phenotypic traits.

These definitions prompt several remarks. First, unlike for the 1993 census, they are not based on self-perception of ethnic affiliation or on categorization of geographic origin by birthplaces of the individuals or their parents; instead they are based on phenotypic and external characterization applied by interviewers - the arbitrariness this entails is the necessary price for apprehending the "racial" categories of common language. Second, we have classified the population using a characteristic of the household, not of the individual, with a fairly broad definition for African Colombian households. In this way the analysis can be extended to a wide range of $\equiv d$-race situations, both in the biological sense (a mixed-race populatid and in terms of household composition (mixed-race households $\left.{ }^{(8)}\right)$. From this perspective, restricting attention to the main family nucleus is a limitation; but it is unavoidable because characterization of the household by the interviewer is based on visual observation of the individuals, and this has to be limited to remain workable.

Household characterization, though used to define the reference population of the two samples, is not mechanically attributed to individuals - all persons present at the time of the visit are characterized individually. The interviewer attributes to the respondent one phenotype from among six categories that command broad semantic acceptance in Cali: negro, mulato, indigena, mestizo, blanco ${ }^{(9)}$, other. In addition, in each household of the sample, one person selected for the biographical part of the survey (see infra) answers an open-ended question on his or her own skin colour ${ }^{(10)}$, thereby creating a link between the respondents' self-

(8) In most mixed situations (all those occurring within the h.h.'s family nucleus), the household is classified as African Colombian; this constitutes an additional arbitrary element in the definition and should be taken into account in the analysis.

(9) In their phenotypic sense, the adjectives negro and mulato refer to African ancestry, dominant in the former case, combined with indigenous or European ancestry in the latter. The indigena category applies to "pure" Indians (a small minority in Colombia). The word mestizo covers all crossings of native, European and African populations, without the specific features of any one being dominant (this is the largest category), and last, the word blanco is used only for European phenotypes.

(10) The phrasing of this question is a translation of the question that has been successfully used in Brazil's census since 1980: “Cual es su color de piel?”. In Brazil, the pre-coded question uses the following categories: "branco" (white), "preto" (black), "pardo" (mulatto), "amarello" (yellow), and "indio" (Indian). Since 1980, the phenotypic characterization of the population has become general in both public and private surveys (household surveys, market research, opinion polls, etc.). The debate in this country is no longer on the definition of those categories, which are almost unanimously acknowledged to be "useful", but rather on how to analyse them and on the scientific, political or commercial use that is made of them. 
perception and their external characterization. The phenotypic category of households and individuals is thus merely one of the possible categories for population analysis, and we refer to the "population of African Colombian households" or to the "African Colombian population" (see section II). However, this vague ethnic terminology, modelled on the African American category of the United States, and which we have adopted because it is now widely used in Colombia, should not mislead; the categorization used is phenotypic. In summary, its justification rests on two main points:

1. Colombia's black and mulatto population suffers in an objective sense from social and spatial segregation, and various forms of stigma and discrimination.

2. The processes of differentiation and division usually operate on a phenotypic, rather than ethnic, principle. We want the survey to yield information on the contents and roles of those segregating racial categories, as expressed in the discourse of the protagonists.

Lastly, some precautions are in order when analysing the figures produced using these different characterizations of the population. The definition of the main family nucleus included children of only one of the partners and those adopted by the head of the household or his or her spouse. But this extension was not always understood or accepted by subjects, and African Colombian households, as identified on our definition, may as a result be slightly under-counted (see Table 1). Furthermore, when the members of a household were repeatedly absent at the time of visits, the household sometimes had to be characterized indirectly by using statements from neighbours; however, since the phenotypic categories used are based on a wide consensus, we believe that those few indirect characterizations will not introduce any bias. The most serious question concerns the possible effect of the interviewer's phenotype, and more generally of the interviewer/respondent interaction, on the subjective questions and particularly the one about skin colour. Half of the interviewers were black or mulatto (10 out of 20), the other half were white or $\equiv$ ed-race; half were men and half women. Analysis of the results (see $i, \nabla$ ) reveals that the effect of gender is as significant as that of phenotype, and that the interviewer's characteristics have a small influence. Among all the persons externally characterized as black or mulattos, the proportion of those characterizing themselves as having a black skin is 3-4\% higher among those who were interviewed by men or by persons who were also black or mulatto (though the effect is no longer significant when "negra"" and "morena" answers are aggregated).

Overall, the inevitable variations that occur in the characterization of individuals and households by interviewers had no systematic influence either way on the size of a given population. The distinction between African Colombian and non-African Colombian households is thus statistically operational and, as will be seen in the next section, is pertinent 
when comparing the characteristics of households and individuals living in different "socio-racial" environments.

Beyond these methodological issues, however, the measurement of demographic, economic or cultural attributes, which is necessary, in the words of A. Desrosières(11), for "social facts to become things", cannot reify or naturalize any category, and even less so in the case of a phenotypic classification. There are strong methodological conditions for our approach not to produce the bias rightly criticized by A. Blum:

"[...] of building categories that are either meaningless or merely vague expressions of 'common sense'. There is serious risk of producing an illusion of coherence and of favouring this stratification at the expense of any genuine confrontation between various determinants." (Blum, 1998, p. 576, my emphasis).

Among these determinants, the writer emphasizes the importance of the variety of the migrants' itineraries and the multiple factors underlying them, and concludes that the ethnic or social categories "observed" at the time of the survey cannot be analysed without reference to individual life histories (ibid, p. 586) - an opinion that we fully share. In fact, because of its high mobility in particular, Colombia's black population has no homogenous demographic, social or cultural characteristics. Analysis must thus be based on an observation system (concepts, sampling(12), questionnaires) that can handle all the factors of heterogeneity - the geographic origins of migration flows, inter and intra-urban residential itineraries, circumstances of economic, social and cultural insertion, etc.

This objective in particular influenced the design of the questionnaire(13) (Barbary, 1998). The first part deals with the characteristics of the household and the individuals: housing conditions (or characteristics) and appliances available to the household, social and demographic characteristics of its individual members (observed phenotype, sex, age, civil status, educational level, main and secondary activities, a summary of their migration history, their places of residence during the year before the survey in the metropolitan zone), visits to place of origin, the household's social and political participation and network of domestic solidarity. The second part corresponds to the methodological imperative emphasized above and takes the form of an interview with one household member aged at least 18, about his or her residential, familial and occupational history ${ }^{(14)}$. Lastly, there are two modules of open-ended and semi-open-ended

(11) Desrosières, 1993, p. 412. This book is a reference for analysis of the historical and social processes in the construction of statistical categories.

(12) Interested readers can find a full account of the sampling methodology in Barbary et al., 1999, pp. 15-19.

(13) It is based on the experience acquired through various IRD, INED, INSEE and DANE surveys. M. Agier (anthropologist), O. Barbary (statistician), O. Hoffmann (geographer), P. Quintin (anthropologist), F. Urrea (sociologist) and H.F. Ramírez (statistician) contributed to its development.

(14) See the methodological summary recently published by the Biographical Approach Task Force, Antoine et al., 1999. 
questions on perceptions and opinions of the person who has participated in the biographical survey, dealing with two themes of particular interest to the study: (i) discrimination and (ii) the quality of life in the neighbourhood and violence.

\section{Early results and analytical goals}

Processing of the survey started three years ago and is yielding far more information than can be summarized here(15). We present only certain preliminary conclusions concerning three questions that are central to this study. How to identify and characterize Cali's African Colombian population? What assessment can be made of social and racial segregation in the city, and its perception by the respondents? What are the main determinants of the answers to questions on ethnic self-perception and skin colour asked in the census and the survey? The answers we supply, though still incomplete, lead to a set of more detailed hypotheses that will serve to guide future analysis.

\section{The African Colombian population in Cali: numbers, racial mixture, mobility}

For the purposes of social and demographic characterization, three definitions have been selected for the "African Colombian" population:

1. the population of African Colombian households, i.e. the population of households in which the interviewer has attributed the black or mulatto phenotype to at least one member of the main family nucleus;

2. the black or mulatto population, i.e. the population of individuals who were characterized as such by the interviewer;

3 . the population of people who described their own skin as black (negra), mulatto (mulata) or dark brown (morena), i.e. those people who, in answering the question "¿Cuál es su color de piel?", used one of the three adjectives that clearly denote, in the Cali idiom, African ancestry.

The first contribution of the survey is an estimation of the numbers in each of these categories and their complement - i.e. the "non-African Colombian" populations (Table 1). The most remarkable feature is the discrepancy between the African Colombian population estimated from

(15) The survey was wholly funded by Colciencias, the Colombian public research agency. The first results, which were presented at an international seminar in Cali in December 1998, are in CIDSE's “documentos de trabajo” series, nos. 38 (Barbary et al., 1999), 39 (Agudelo, Hoffmann, Rivas, 1999), 40 (Vanin, Agier, Hurtado, Quintín, 1999), 41 (Rivas, 1999), 42 (Hoffmann, Pissoat, 1999), 48 (Arboleda, Arias, Urrea, 2000), 49 (Quintin, Ramirez, Urrea, 2000) and 50 (Agudelo, Hurtado, Rivas, 2000). 
census data and that observed in the survey. We knew that the proportion established by the census $(10.5 \%)$ was greatly underestimated, but our highest hypotheses (about 16\%) proved to be far below reality - in the survey sample it is actually about $30 \%$ for the population of African Colombian households. The figures for individuals characterized as black or mulatto $(25 \%)$ and for those who identified themselves as such $(17.6 \%)$ - the latter figure is to be compared with the $0.5 \%$ rate registered by the ethnic question in the census in Cali - reveal the extent of the invisibility of the urban African Colombian population in the existing Colombian statistical system. A second survey using the same methodology and conducted one year later for the World Bank and the Cali municipal authority roughly confirms these figures. In June 1999 the population of African Colombian households in Cali comprised 769,000 people (37\% of the total population) and the population characterized as black or mulatto was 606,000 (31\%). The difference with the 1998 survey is accounted for by the much higher figure for the mulatto population $(19 \%$ as against $10 \%$ in the CIDSE/IRD survey), at the expense of the mixed-race population (22\% as against 28\%). The discrepancy illustrates the importance of the interviewers' training and of a semantic consensus about the phenotypic categories. Once these results were known, the Colombian National Statistics Bureau included a social exclusion module in the most recent household survey covering the 14 largest cities in the country; this contained a statement by the respondents themselves on their skin colour, established by reference to a set of four photographs they were shown (ENH, DANE, 2001). Cartagena is the only city in which a majority of the population self-identified as black and mulatto (50\%), whereas in Cali a proportion of $26.5 \%$ was registered for the photographs corresponding to these two phenotypes together - a figure close to that obtained in our survey using external characterization by the interviewers. The mean figure for all 14 towns was $17.9 \%$, a figure that again should be compared with the $3.3 \%$ national average obtained from the ethnic question in the census. We believe that this set of results provides strong a posteriori validation of the options chosen for the survey.

Another significant finding, displayed in the second panel of Table 1, is the extent of raci Elixing among the populations of Cali - this affects both the African Chbian and the control households, and is observed both in its "biological" dimension (the proportion of mulatto and race populations) and in household composition (the frequency o $D$ terracial unions). By the interviewers' characterization, only $48 \%$ of the individuals were black in the African Colombian households, and $63 \%$ were white in the non-African Colombian ones. The respondents' answers confirm the importance of the phenomenon by showing the diversity of the individuals" "phenotypic position", and hence the need to treat with caution the classification of households made by the interviewer. Respondents select the "racially tainted" colours (negra, morena, mulata, blanca) less often than the corresponding external classifications (negro, mulato, 
blanco); the largest disparity is for the "blanco" category (46\% of the interviewers' characterizations for all the households, as against $30 \%$ of the respondents' statements). In fact, a majority of respondents (53\%) opted for $\equiv$ ed-race colours (canela, trigueña, castaño, café, etc).

TABLE 1.- POPULATION ESTIMATES BY PHENOTYPIC CHARACTERIZATION

\begin{tabular}{|c|c|c|c|c|c|c|c|}
\hline \multicolumn{8}{|c|}{ Population by interviewers' characterization of households ${ }^{(1)}$} \\
\hline \multirow{2}{*}{ Interviewers' characterization } & \multicolumn{4}{|c|}{ Households } & \multicolumn{3}{|c|}{ Individuals in households } \\
\hline & \multicolumn{2}{|c|}{ Numbers } & \multicolumn{2}{|l|}{$\%$} & Numbers & \multicolumn{2}{|r|}{$\%$} \\
\hline African Colombian households & \multirow{3}{*}{\multicolumn{2}{|c|}{$\begin{array}{l}106,085 \\
249,581 \\
355,666\end{array}$}} & \multirow{3}{*}{$\begin{array}{r}29.8 \\
70.2 \\
100.0 \\
\end{array}$} & & \multirow{3}{*}{$\begin{array}{r}460,873 \\
1,091,743 \\
1,552,616\end{array}$} & \multirow{3}{*}{\multicolumn{2}{|c|}{$\begin{array}{r}29.7 \\
70.3 \\
100.0\end{array}$}} \\
\hline Control households & & & & & & & \\
\hline Total & & & & & & & \\
\hline \multicolumn{8}{|c|}{ Distribution of individuals by interviewers' characterization(2) } \\
\hline Interviewers' characterization & Negro & Mulato & Indigena & Mestizo & Blanco & Otro & Total \\
\hline $\begin{array}{l}\text { African Colombian households } \\
(\%)\end{array}$ & 47.9 & 33.2 & 0.6 & 11.5 & 6.7 & 0.1 & 30.4 \\
\hline Control households (\%) & 0.3 & 0.5 & 1.0 & 35.1 & 63.2 & 0.0 & 69.6 \\
\hline Total $(\%)$ & 14.7 & 10.4 & 0.9 & 27.9 & 46.1 & 0.0 & 100.0 \\
\hline Numbers & 191,126 & 134,912 & 11,237 & 361,674 & 596,928 & 303 & $1,296,180$ \\
\hline \multicolumn{8}{|c|}{ Distribution of individuals by respondents' self-characterization ${ }^{(3)}$} \\
\hline $\begin{array}{c}\text { Respondents' } \\
\text { self-characterization }\end{array}$ & $\begin{array}{l}\text { Negra and } \\
\text { assim. }\end{array}$ & $\begin{array}{l}\text { Morena, } \\
\text { Mulata }^{(4)}\end{array}$ & $\begin{array}{c}\text { Canela } \\
\text { and } \\
\text { assim. } \\
\text { (5) }\end{array}$ & $\begin{array}{l}\text { Trigueña } \\
\text { and } \\
\text { assim. }{ }^{(6)}\end{array}$ & $\begin{array}{l}\text { Blanca } \\
\text { and } \\
\text { assim. }\end{array}$ & $\begin{array}{l}\text { Other } \\
\text { answers }\end{array}$ & Total \\
\hline $\begin{array}{l}\text { African Colombian households } \\
(\%)\end{array}$ & 32.4 & 19.8 & 8.2 & 33.1 & 4.5 & 2.0 & 29.8 \\
\hline Control households (\%) & 0.7 & 2.1 & 10.2 & 40.0 & 40.4 & 6.6 & 70.2 \\
\hline Total $(\%)$ & 10.2 & 7.4 & 9.6 & 38.0 & 29.7 & 5.2 & 100.0 \\
\hline Numbers & 36,146 & 26,303 & 34,021 & 135,085 & 105,641 & 18,470 & 355,666 \\
\hline \multicolumn{8}{|c|}{$\begin{array}{l}\text { (1) The numbers of households and individuals are extrapolated to the whole population covered by the } \\
\text { survey - 355,666 households and } 1,552,616 \text { individuals, i.e. about } 78 \% \text { of the total population of the city } \\
(1,982,000) \text {, as estimated by projection of the census population to } 30 \text { June } 1998 \text {. } \\
\text { (2) The distribution is that observed among individuals visually characterized by the interviewers: } 7,022 \text { of } \\
\text { the } 8,250 \text { people included in the sample, or } 85 \% \text {. These data are weighted by the survey's extrapolation fac- } \\
\text { tors. } \\
\text { (3) The distribution is that observed among individuals who answered the open-ended question on skin } \\
\text { colour ( } 1,824 \text { out of the } 1,880 \text { people who were asked the question), and who can then be considered to be } \\
\text { representative of the population aged } 18 \text { and over ("biographic" sub-sample). The answers were classified } \\
\text { using the adjectives mentioned, used alone or with other words. These data are weighted by the survey's } \\
\text { extrapolation factors. } \\
\text { (4) Dark-skinned, mulatto; }{ }^{(5)} \text { Cinnamon; (6) Literally "wheat-coloured", usually translated as light brown or } \\
\text { olive. } \\
\text { Source: CIDSE/IRD survey, June } 1998 \text {. }\end{array}$} \\
\hline
\end{tabular}

A third important finding concerns the migration structure of the African Colombian population, which again diverges from that obtained by the census. First, African Colombian households contain twice as many Cali natives $(57 \%)$ as expected ${ }^{(16)}$ - a figure close to that observed in the

(16) This occurred because, as noted, a large proportion of the Cali-born descendants of migrants could not be included in the census estimate of the population "of African Colombian origin", strictly on the basis of place of birth. 
control households $(59 \%)$, thereby giving the lie to the connection often made in the literature between the black population and recent migration. In addition the places of origin of African Colombian migrants to Cali are surprisingly varied(17). The Pacific region is of course confirmed as the foremost place of origin ( $42 \%$ of the total), but the urban and rural hinterland of Cali (the northern part of the Cauca departamento and other municipios of the Valle) makes a large contribution (33\%). And above all, the volume of medium- and long-distance migration from regions outside the area with a majority of black population - mainly the altiplano of the Cauca and the Nariño, the coffee plantations area, the Antioquia and Bogota - accounting for $25 \%$ of the total, far exceeds earlier hypotheses. Such diversity of geographic origins attests to the high mobility that characterizes the recent history of Colombia's black populations and is doubtless associated with a rich variety of migration itineraries, the details of which can be established from the analysis of the biographical data gathered in the survey.

\section{Segregation and discrimination: Leads for the analysis... and the respondents' point of view}

As a corollary of inter-racial unions and diversity of origins and migration histories, we expect the African Colombian population to be very heterogeneous with respect to social and economic conditions. Analysis of the results produces detailed conclusions, of which only a summary can be presented here.

The survey has confirmed a generally accepted view - namely that the social and spatial segmentation of the Cali urban space coincides with segregation of the black population ${ }^{(18)}$. The phenomenon is observed both at the residential level, with a relative concentration of this population in the city's poorest areas (Barbary et al., 1999, pp. 37-41,71-76), and in the living conditions of the households, with wide disparities, always to the detriment of African Colombian households, on such indicators as overcrowding of housing, access to public services, and home appliances (ibid. pp. 53-61). More detailed analysis, however, shows that the process behind such situations is complex and that its intensity varies greatly depending on other factors of spatial or socio-economic segmentation. Bruyneel and Ramirez, for example, have shown that for overcrowding of the home, the relative disadvantage of African Colombian households is the same at all points on the social scale (ibid. p 56), whereas for access to

(17) For a detailed analysis of migration flows and their recent dynamics, see Barbary et al., 1999, pp. 41-49.

(18) According to detailed statistical measurements of spatial segregation (dissimilarity and square root indices, Hutchens, 2001) which cannot be described in detail here, the degree of segregation of the black population in Cali is still far below that in US cities (see Dureau, Barbary et al., 2002). There the index values are 5-10 times higher, to judge from the extensive American literature on the theme, a good methodological and empirical summary of which is given in Massey and Denton, 1988, and updated in Massey, White and Phua, 1996. 
services and household appliances, it is concentrated in its middle range, the poorest and richest households having parity with their non-African Colombian counterparts (ibid. pp. 58, 59). Moreover, these segmentation mechanisms cannot be analysed simply as an endogenous product of a social order segregated on racial lines; they are also the result of the strategies and opportunities specific to the migration networks of the populations with different geographical and social origins (ibid., pp. 41, 49, 87 and 88). Those origins are extremely important as a factor of differentiation of the African Colombian population but also of internal heterogeneity. Accordingly, the geographic, economic and cultural segmentation of the complex set of origins and itineraries that determine social and spatial segregation in Cali is of central interest for analysis.

Despite this heterogeneity, the diagnosis that emerges from the survey population's perceptions and opinions regarding discrimination is unequivocal: the majority opinion in Cali, among people of all skin colours and social conditions, is that discrimination does exist, in employment and in other situations, usually against blacks, but also against Indians, the poor, the elderly, women, etc. Of the people interviewed, $65 \%$ replied "yes" to the question on the existence of discrimination at work - 60\% among control households, $77 \%$ among African Colombian households, and rising to $82 \%$ among those women who were characterized as black. Moreover, over one-third of the people who believe that discrimination exists think it is frequent (believing it to be practised by many if not most employers). The respondents clearly identify the two major reasons for occupational discrimination as racial identity and social class: $55 \%$ mentioned blacks as the largest category of population experiencing it, and $24 \%$ the poor and the uneducated. The elderly (5\%), women $(3 \%)$, the young $(2 \%)$, and Indians $(0.5 \%)$ come far behind. Likewise, over half the members of the sample believe that blacks are treated less well by the police and in the workplace, and about $30 \%$ believe the same is true in hospitals and health centres, in primary and secondary schools, in public transportation and in dealings with officialdom. The only exception concerns the existence of racial discrimination at the neighbourhood level, which was rarely mentioned (18\%). Lastly, $32 \%$ of the black population said that they had personally suffered discrimination, compared with only $15 \%$ of the mulatto population and $10 \%$ of the white population. Such situations are even more frequent in certain segments of the population, almost always in employment contexts: black women employed as domestic servants, black persons discriminated against in company recruitment, particularly in the retailing sector. Skin colour is again given as the prime reason for discrimination(19), with social class and sex only coming next(20), though explicit references to both types of factors are quite fre-

(19) "por ser negra (o)", "por negra(o)", "por el color de piel"... "because I'm black", "as a black person", "because of my skin colour", etc.

(20) "por no haber estudiado", "por ser pobre, a uno lo tratan mal", "por vivir en el distrito", "por ser mujer"... "because I'm not educated", "when you are poor, you are ill-treated", "because I live in the district", "as a woman", etc. 
quent $^{(21)}$. The respondents thus give a timely reminder that the racial and social motors of discrimination operate in parallel, by intensifying biological and socio-cultural differences, usually without distinguishing between them.

Significant variations ${ }^{(22)}$ do of course occur in the perception of discrimination. For example, the data show women to be more aware of it, their frequency of "yes" answers being usually higher than men's, which is explained by the cumulative impact of the risks of racial, social and gender discrimination. In the same logic of exposure to risk, a phenotypebased gradient is also observed, though not running strictly from clearest to darkest skin colour. Frequencies generally increase in the following

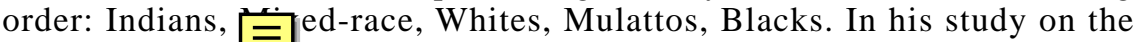
population of $\mathrm{M}$ illin, P. Wade (1997) gives a good analysis of the construction of racial identity among the mixed-race majority and of how it is used socially and culturally in the paisa region, the symbolic heart of the Colombian melting pot. The same "whitening-up" strategies he observes and that he links to "the racial order" established by the Creole elites, are probably also at work in Cali, "the black city". They would account for the relatively low levels of racial discrimination reported by the indigenous and mixed-race population.

Having said that, the diagnosis given by the white and mixed-race population is consistent with that of African Colombians, and sometimes equally harsh, as for example concerning police prejudice against blacks or the frequency of discrimination at work. This is the first element that qualifies the picture drawn so far of racial inequality in Cali - the black population is not alone in finding its condition shocking, and high levels of awareness and solidarity are observed in white and mixed-race public opinion. Further evidence of this is the low frequency noted earlier of racial discrimination felt to exist within neighbourhoods, which is not explained by a racial and social homogeneity that seldom exists at this level. Likewise, instances of violence personally experienced by the respondents are rarely attributed to racism. This lack of a connection between racism and violence, in a country where the latter is considered endemic, contrasts with other national contexts, such as the United States and Europe, and invites in-depth analysis of the theme to uncover the sources and social effects of this "quiet Colombian-style racism". A hypothesis can thus be formulated: although discrimination by skin colour undoubtedly exists in Cali, it would appear not to be primarily the expression of common, everyday racism pervading social relations. In fact,

(21) "por ser negra y pobre", "dis que por no ser bachiller y ser negra", "por no tener estudios y ser pobre", "por ser pobre y vivir en Siloé", "ser mujer pobre"... "because I'm black and poor", "they say it's because I haven't been through secondary education, and because I'm black", "because I'm uneducated and poor", "because I'm poor and I live at Siloé", "to be a poor woman", etc. level.

(22) i.e. after the sampling error has been taken into account, usually at the $99 \%$ confidence 
Cali's reputation as a welcoming city is justified, and is based on a social climate that is still calm, albeit threatened by the severe political and economic crisis affecting the country. What respondents criticize most, it seems to us, is the "institutional" discrimination in companies and public or private services, where it is usually intertwined with class relations. But more analyses are needed to support this thesis, as an opinion survey alone cannot provide a conclusive demonstration.

\section{Variations in the assertion of a "black identity"}

With the 1993 census and the 1998 CIDSE/IRD survey we possess two bodies of answers about ethnic and phenotypic self-perception. We are thus in a position to relate those answers, first with the individual socialdemographic variables provided in both sources (sex, age, education, socio-occupational category), second with the descriptors of the context in which they were given - geographic location of residence, size of locality, zone of residence and migration status of the individuals interviewed in Cali. With this second group of variables, and using the resources of the bibliography, we can obtain data on the regional and local environments and their political and cultural dynamics, whose influence is expected to be significant. Lastly, in the case of the survey conducted in Cali, two more potential determinants are also available - the individuals' phenotypes as observed by the interviewers, and the interviewers' own characteristics (sex and phenotype).

What combination of these factors accounts for the variations of ethnic self-perception in the black population area of south-west Colombia(23), and of self-perception of skin colour among the African Colombian population of Cali? What hypotheses does the analysis suggest about the process of constructing a "black" identity in Colombia and about the variations in its form depending on the context of the actors' speech and their individual or collective characteristics? We supply some tentative answers by using logistic regressions to model the effect of the explanatory variables on the two response variables ${ }^{(24)}$ :

1. Answers to the ethnic question in the 1993 census are coded "Yes" for persons who answered that they belong to a "black community".

2. Answers to the question on skin colour in the CIDSE/IRD survey are coded "Yes" for persons whose answer included the adjective "black", either alone or in an affirmative context.

\footnotetext{
(23) This is taken here to mean all the Pacific coast municipios in the departamentos of Valle del Cauca, Cauca and Nariño, and the whole of the Chocó departamento.

(24) The procedures used are LOGISTIC and CATMOD, from SAS (version 6.08), in which this test is based on Wald's chi-square statistic (1943). Unfortunately the sampling design cannot be taken into account with this version. Since the test is very sensitive to sample size, we have used the unweighted data for the CIDSE/IRD survey.
} 


\section{In the Pacific region at the time of the census}

Although the ethnic question in the 1993 census failed, as noted, at the national level and in the larger cities, it successfully measured at both general and local levels the assertions of black community affiliation in the Pacific region. For the whole population aged 18 and over, the frequency of "yes" answers was $44.5 \%$, with large local variations, ranging from only $3 \%$ on the Pacific coast of the Valle (Buenaventura municipio), to $27 \%$ on the Pacific coast of the Nariño, $71 \%$ on that of the Cauca and $81 \%$ in all the southern and central municipios of the Chocó, and to over $95 \%$ in the north of this departamento and in its capital, Quibdó. It is tempting to see this as the influence of the emergence of the "comunidades negras" social movement and of the economic and territorial stakes involved. This movement actually originated in Quibdó and in the rural area north of the Chocó in the late 1980s, and shortly before the census, it obtained the passing of Law 70. Logistic regression confirms the hypothesis of a strong relation between this process and the self-characterization of ethnic affiliation.

In the complete model of the main effects (Table 2), the six parameters corresponding to the variables considered independently from one another (sex, age, education, socio-occupational category, size of locality and region of residence) are all significant ${ }^{(25)}$. However, the effect of the regional context is clearly stronger than all the others. It accounts for a proportion of the variance in the answers ten times larger than the next two effects, which are socio-occupational category and size of locality. Sex and education, by contrast, have very small effects. All other things being equal, therefore, the residents of a municipio in the northern Chocó are three times more likely to answer "yes" than those on the Pacific coast of the Nariño, whereas on the Pacific coast of the Valle, the probability is four times smaller. Also clear is the role of socio-occupational category: the status of independent or family workers in agriculture, fishing and mining (a positive effect, particularly in the mining sector where the probability is 2.5 times greater) contrasts with that of blue-and white-collar workers and employers in all sectors (probability reduced by 5 to $10 \%$ ). For the size of place of residence, the second-order interactions model (not presented in tabular form) shows that its main effect gives way to crossed effects of socio-occupational category and region of residence. The model thus identifies the social and geographic "niche" where assertion of ethnic identity is strongest - among independent or family workers of the mining industry in villages with populations under 5,000 but mainly in small towns of the Chocó with populations of 5,000 to 50,000. Lastly, it should be noted that

(25) Possible interactions cannot be ruled out with this model, as the hypothesis of independence between the variables is rejected; despite this, the adjustment of the marginal frequencies is quite good (standard deviation of residuals: $8 \%$ ). On the other hand, the independence hypothesis can be accepted for the model that includes all second-order interactions (no higherorder crossed effects), and we discuss some of those results. 
in the interactions model, the assertion of ethnic identity is strong among those residents in the northern Chocó with higher education, who played a key role in the mobilization that led to constitutional reform and to Law 70.

These results have to be interpreted against the "neo-communalist" background of the political birth of the African Colombian identity. As M. Agier points out:

"It was only with development-oriented policies for the Pacific region, and with the rise, on the global scale (...), of a discourse favourable to regionalism, localism, ethnic identity and environmental protection, that the Pacific African Colombian identity began to emerge, between the 1980 s and the 1990s"(26).

Access to the status and subsidies instituted under Law 70 was conditional on the creation of a cultural and ethnic identity linked chiefly to a territory (the rural regions of the Pacific coast) and to an economic system of resource use based on small family business combining agricultural, fishing and mining activities. Since both are under threat (Agier et al., 2000 , p. 18), it is not surprising that the populations most directly concerned by the new legal measures "conform as closely as possible" to the affirmation of a neo-ethnic identity that the constitution, in a sense, demands of them.

In this context, modelling the responses to the census question reveals an assertion of black community membership that could be described as "neo-ethnic", and that is socially and politically instrumentalized by a set of actors. This approach, however, does not inform about the problem of the black and mulatto populations who migrated out of the geographical area covered by Law 70 and who now form the majority. What are the implications for the processes of construction of a black identity in the cities given that, as we have seen, a neo-ethnic assertion is almost or completely non-existent in that setting? If these processes exist, on what are they based?

\section{In Cali during the survey}

The data collected in Cali provide us, in addition to the variables already considered (sex, age, education, socio-occupational category), with four new variables. These are the respondent's phenotypic characterization as observed by the interviewer, the interviewer's sex and phenotype ${ }^{(27)}$, the residential zone in Cali(28), and the migration status(29). The

(26) Agier et al., 2000, p. 61.

(27) Four categories: black or mulatto female, black or mulatto male, white or

female, white or ${ }_{(28)}$ Four ${ }^{\text {d-race male. }}$ ries: working-class areas in the east of the city, middle-class areas thear the centre and in the caol, working-class areas on the western outskirts, residential areas in the south of the city.

(29) Fifteen categories obtained by crossing birthplaces - Cali natives vs. migrants - with places of origin, the latter being defined as the region where the migrants or, in the case of natives, their parents were born (in the CIDSE/IRD survey, the parents' birthplaces were known for all the individuals). 
TABLE 2.- EFFECT OF SIX VARIABLES ON THE PROBABILITY OF "YES" ANSWERS TO THE QUESTION ON BLACK COMMUNITY MEMBERSHIP IN THE CENSUS (LOGISTIC REGRESSION)

\begin{tabular}{|c|c|c|c|c|c|}
\hline \multicolumn{6}{|c|}{ 1. Chi-square test for variables in the model } \\
\hline Variables & \multicolumn{2}{|c|}{ Degrees of freedom } & \multicolumn{2}{|l|}{$\chi 2$} & Probability \\
\hline $\begin{array}{l}\text { Constant } \\
\text { Sex } \\
\text { Age } \\
\text { Level of education } \\
\text { Socio-occupational category } \\
\text { Size of the place of residence } \\
\text { Region of residence } \\
\end{array}$ & $\begin{array}{r}1 \\
1 \\
2 \\
5 \\
16 \\
4 \\
5 \\
\end{array}$ & & $\begin{array}{r}0.41 \\
80.08 \\
209.26 \\
1294.58 \\
6693.06 \\
5052.80 \\
57650.91 \\
\end{array}$ & & $\begin{array}{l}237 \\
000 \\
000 \\
000 \\
000 \\
000 \\
000\end{array}$ \\
\hline \multicolumn{6}{|c|}{ 2. Estimation of the parameters } \\
\hline Categories of the variables & $\begin{array}{l}\text { Estimated } \\
\text { parameter }\end{array}$ & Significance & $\begin{array}{l}\text { Estimated } \\
\text { response }\end{array}$ & $\begin{array}{c}\text { Residual } \\
\text { (obs.-est.) }\end{array}$ & $\begin{array}{c}\text { Marginal } \\
\text { effect }\end{array}$ \\
\hline Constant & -0.00820 & n.s. & $49.8 \%$ & $-5.3 \%$ & \\
\hline $\begin{array}{l}\text { Men } \\
\text { Women (Ref.) }\end{array}$ & $\begin{array}{r}-0.0525 \\
0.0525\end{array}$ & $* * *$ & $\begin{array}{l}25.5 \% \\
27.6 \%\end{array}$ & $\begin{array}{r}-1.8 \% \\
5.6 \%\end{array}$ & $-2.1 \%$ \\
\hline $\begin{array}{l}\text { Aged 31-50 } \\
\text { Over } 50 \\
\text { Aged 18-30 (Ref.) }\end{array}$ & $\begin{array}{c}0.00626 \\
-0.1044 \\
0.09814\end{array}$ & $\begin{array}{l}\text { n.s. } \\
* * *\end{array}$ & $\begin{array}{c}\text { n.s. } \\
23.7 \% \\
27.6 \%\end{array}$ & $\begin{array}{l}\text { n.s. } \\
1.7 \% \\
5.6 \%\end{array}$ & $\begin{array}{c}\text { n.s. } \\
-3.9 \%\end{array}$ \\
\hline No education or no answer & 0.3710 & $* * *$ & $32.2 \%$ & $2.2 \%$ & $4.6 \%$ \\
\hline Uncompleted primary education & -0.1604 & $* * *$ & $21.8 \%$ & $2.0 \%$ & $-5.8 \%$ \\
\hline Uncompleted secondary education & -0.0536 & $* * *$ & $23.7 \%$ & $-1.9 \%$ & $-3.9 \%$ \\
\hline Completed secondary education & -0.1148 & $* * *$ & $22.6 \%$ & $-5.2 \%$ & $-5.0 \%$ \\
\hline University education & -0.1928 & $* * *$ & $21.2 \%$ & $1.0 \%$ & $-6.3 \%$ \\
\hline Completed primary education (Ref.) & 0.1506 & & $27.6 \%$ & $5.6 \%$ & \\
\hline
\end{tabular}




\begin{tabular}{|c|c|c|c|c|c|}
\hline Non-working & 0.0961 & $* * *$ & $33.6 \%$ & $-13.6 \%$ & $6.0 \%$ \\
\hline Students & 0.1648 & $* * *$ & $35.1 \%$ & $10.4 \%$ & $7.5 \%$ \\
\hline Unemployed & -0.0997 & $* * *$ & $29.3 \%$ & $-10.4 \%$ & $1.8 \%$ \\
\hline Domestic workers & -0.3742 & $* * *$ & $24.0 \%$ & $-10.3 \%$ & $-3.6 \%$ \\
\hline Blue-and white-collar (B/W) workers, sector unknown & -0.1681 & $* * *$ & $27.9 \%$ & $-5.7 \%$ & $0.4 \%$ \\
\hline B/W, Agriculture-Fishing-Mining-Construction-Transport & -0.5120 & $* * *$ & $21.6 \%$ & $0.5 \%$ & $-6.0 \%$ \\
\hline B/W, Industry-Electricity-Gas-Trade-Services & -0.4247 & $* * *$ & $23.1 \%$ & $-11.6 \%$ & $-4.5 \%$ \\
\hline B/W, Financial and Housing, Public Sector & 0.00113 & n.s. & n.s. & n.s. & n.s. \\
\hline Status unknown, Agriculture-Fishing-Mining-Construction-Transport & 0.3415 & $* * *$ & $39.2 \%$ & $7.5 \%$ & $11.7 \%$ \\
\hline Status unknown, other sectors & 0.0162 & n.s. & n.s. & n.s. & n.s. \\
\hline Self-employed and family workers (SE/FW), sector unknown & 0.3187 & $* * *$ & $38.7 \%$ & $0.5 \%$ & $11.1 \%$ \\
\hline SE/FW, Agriculture and Fishing & 0.3445 & $* * *$ & $39.3 \%$ & $25.4 \%$ & $11.7 \%$ \\
\hline SE/FW, Mining & 1.4624 & $* * *$ & $66.4 \%$ & $-3.3 \%$ & $38.9 \%$ \\
\hline $\mathrm{SE} / \mathrm{FW}$, other sectors & -0.1917 & $* * *$ & $27.5 \%$ & $-13.2 \%$ & $-0.1 \%$ \\
\hline Employer, Agriculture-Fishing-Mining & -0.3769 & $* * *$ & $23.9 \%$ & $9.4 \%$ & $-3.6 \%$ \\
\hline Employer, other sectors & -0.4110 & $* * *$ & $23.3 \%$ & $76.7 \%$ & $-4.2 \%$ \\
\hline Homemakers (Ref.) & -0.18703 & & $27.6 \%$ & $5.6 \%$ & \\
\hline Urban $<5,000$ persons & -1.1882 & $* * *$ & $6.2 \%$ & $-6.2 \%$ & $-21.3 \%$ \\
\hline Urban 5,000-49,999 & 0.8757 & $* * *$ & $34.4 \%$ & $12.8 \%$ & $6.8 \%$ \\
\hline Urban 50,000-99,999 & -0.0173 & n.s. & n.s. & n.s. & n.s. \\
\hline Urban > 100,000 & -0.2254 & $* * *$ & $14.8 \%$ & $-3.8 \%$ & $-12.7 \%$ \\
\hline Rural (Ref.) & 0.5552 & & $27.6 \%$ & $5.6 \%$ & \\
\hline Pacific Coast of the Cauca & 0.1087 & $* * *$ & $68.3 \%$ & $-8.2 \%$ & $40.8 \%$ \\
\hline Pacific Coast of the Valle & -3.3417 & $* * *$ & $6.4 \%$ & $-2.8 \%$ & $-21.1 \%$ \\
\hline Southern part of the Chocó & 0.6512 & $* * *$ & $78.8 \%$ & $-9.2 \%$ & $51.2 \%$ \\
\hline Central part of the Chocó & 1.0507 & $* * *$ & $84.7 \%$ & $-6.9 \%$ & $57.2 \%$ \\
\hline Northern part of the Chocó & 3.1589 & $* * *$ & $97.9 \%$ & $-0.2 \%$ & $70.3 \%$ \\
\hline Nariño Pacific Coast (Ref.) & -1.6278 & & $27.6 \%$ & $5.6 \%$ & \\
\hline
\end{tabular}


population used in the regressions comprises all the persons aged 18 and over in the sample, who are of black or mulatto phenotype and who answered the self-perception question. Of those 1,256 persons, $41.6 \%$ reported that they had a black skin, or $65.4 \%$ if the adjectives negra (black) and morena (dark brown) are aggregated. In Cali, the two adjectives have different semantic meanings, depending on the social context in which they are used(30). A useful starting point for identifying some of the factors behind "socio-racial assertion" is thus to analyse those answers that use the adjective negra/o, as opposed to the others(31).

Four main variables help account for the total variance of the answers: phenotype, age, occupational category and migration status, while the others do not cross the significance threshold. The respondents' place of residence seems not to be determinant once the effect of the phenotype is taken into account; this indicates a link between the two variables and points to the "racial specialization" of residential space in Cali mentioned earlier. The first noteworthy result is the absence of interviewer effect. The interviewer/respondent relationship does not have the importance one might have feared, and which anthropologists who are critical of this kind of approach often assign to it.

This four-variable model performs well in predicting individual answers (74\% correct) and for estimating the contingency table frequencies (standard deviation of residuals: $8 \%$ ). The effect of the phenotype predominates by far: it accounts for between 5 and 30 times more of the variance than the other characteristics. Persons with a black phenotype, all other things being equal, are about four times more likely than persons of a mulatto phenotype to describe their own skin colour as black. In this model, however, the hypothesis that variables are independent is rejected. As the sample is too small to model all the interactions, we use only the saturated models in which phenotype is crossed with three other variables (Table 3).

The results lead to conclusions that contrast with those reached about the assertion of ethnic affiliation in the Pacific region. In Cali, the only origin that favours self-reporting of black skin colour to any significant degree is the Pacific coast of the Cauca. Moreover, the significant coefficient is not that corresponding to migrants born in the region but that of their descendants born in Cali (probability more than twice as high as the average). Contrary to what was expected given the massive proportion of respondents in the Chocó who reported membership in the black community, in Cali those born in that departamento are no more likely than people of other origins to describe their skin colour as black, given the

(30) Those meanings are discussed in detail in the French version of this article (Population, 56(5), 2001).

(31) To take the analysis further, it would be worth repeating the exercise with the "negra" and "morena" answers combined so as to test the opposite hypothesis, namely that in certain contexts, the two words are semantically equivalent. 
same phenotypes. On the other hand, the descendants of migrants from the country's interior, whose origins were remote from the black demographic and cultural influences, report a black skin significantly less often (probability reduced by more than one third relative to the average).

TABLE 3.- SIGNIFICANT MAIN EFFECTS AND INTERACTIONS OF SELECTED
CHARACTERISTICS ON THE PROBABILITY OF REPORTING ONE'S SKIN COLOUR
AS BLACK IN THE SURVEY (LOGISTIC REGRESSIONS)

\begin{tabular}{|c|c|c|c|c|}
\hline & $\begin{array}{l}\text { Estimated } \\
\text { parameter }\end{array}$ & $\begin{array}{l}\text { Signifi- } \\
\text { cance }\end{array}$ & $\begin{array}{l}\text { Estimated } \\
\text { response }\end{array}$ & $\begin{array}{l}\text { Observed } \\
\text { response }\end{array}$ \\
\hline \multicolumn{5}{|c|}{ Phenotype and migration status, with interaction } \\
\hline Constant & -0.8776 & $* * *$ & $29 \%$ & $42 \%$ \\
\hline $\begin{array}{l}\text { Phenotype } \\
\text { Black (+) }\end{array}$ & 1.2675 & $* * *$ & $60 \%$ & $57 \%$ \\
\hline $\begin{array}{l}\text { Migration status } \\
\text { Born in Cali, origin Cali (-) } \\
\text { Born in Cali, origin Pacific Cauca (+) } \\
\text { Born in Cali, origin Int. Valle, Cauca, } \\
\text { Nariño (-) } \\
\text { Migrants from the rest of Colombia (-) }\end{array}$ & $\begin{array}{r}-0.3292 \\
1.4795 \\
-0.6902 \\
-0.4223\end{array}$ & $\begin{array}{l}* * * \\
* * * \\
* * \\
* *\end{array}$ & $\begin{array}{l}23 \% \\
65 \% \\
17 \% \\
21 \%\end{array}$ & $\begin{array}{l}29 \% \\
73 \% \\
19 \% \\
21 \%\end{array}$ \\
\hline $\begin{array}{l}\text { Phenotype } \times \text { Migration status } \\
\text { Black, Pacific Nariño migrants }(-) \\
\text { Black, Born in Cali, origin Pacific Nariño (-) } \\
\text { Black, Pacific Valle migrants (-) }\end{array}$ & $\begin{array}{l}-0.7215 \\
-1.0291 \\
-0.6893 \\
\end{array}$ & $\begin{array}{l}* * * \\
* * * \\
* *\end{array}$ & $\begin{array}{l}54 \% \\
55 \% \\
57 \% \\
\end{array}$ & $\begin{array}{l}54 \% \\
55 \% \\
57 \% \\
\end{array}$ \\
\hline \multicolumn{5}{|c|}{ Phenotype and socio-professional category, with interaction } \\
\hline Constant & -1.0808 & $* * *$ & $25 \%$ & $42 \%$ \\
\hline $\begin{array}{l}\text { Phenotype } \\
\text { Black }(+)\end{array}$ & 1.3982 & $* * *$ & $58 \%$ & $57 \%$ \\
\hline $\begin{array}{l}\text { Socio-occupational category } \\
\text { Skilled industrial workers }(+) \\
\text { Unskilled workers, crafts, constr., transp. }(+)\end{array}$ & $\begin{array}{l}0.6552 \\
0.4748\end{array}$ & * & $\begin{array}{l}40 \% \\
35 \%\end{array}$ & $\begin{array}{l}55 \% \\
45 \%\end{array}$ \\
\hline $\begin{array}{l}\text { Phenotype } \times \text { Socio-occupational category } \\
\text { Black, secretaries, admin. staff }(-) \\
\text { Black, skilled crafts }(-) \\
\text { Black, unskilled crafts, constr., transp. }(-)\end{array}$ & $\begin{array}{l}-0.6806 \\
-0.6680 \\
-0.5690\end{array}$ & $\begin{array}{l}* * \\
* * \\
* *\end{array}$ & $\begin{array}{l}50 \% \\
48 \% \\
56 \%\end{array}$ & $\begin{array}{l}50 \% \\
48 \% \\
56 \%\end{array}$ \\
\hline \multicolumn{5}{|c|}{ Phenotype and area of residence in Cali (interaction not significant) } \\
\hline Constant & -1.0087 & $* * *$ & $27 \%$ & $42 \%$ \\
\hline $\begin{array}{l}\text { Phenotype } \\
\text { Black (+) }\end{array}$ & 1.132 & $* * *$ & $53 \%$ & $57 \%$ \\
\hline $\begin{array}{l}\text { Residence in Cali } \\
\text { East poorer neighbourhoods }(+)\end{array}$ & 0.2342 & $*$ & $32 \%$ & $46 \%$ \\
\hline
\end{tabular}


In Cali, the socio-occupational category does not play the same determining role in the assertion of phenotype that it does for the assertion of black community affiliation in the Pacific region. Only skilled industrial workers are more likely to describe their skin colour as black (probability 1.8 times higher than among the non-working population). Last, the squatter settlements (invasiones) on the slopes of the western cordillera, where the population characterized as black is smallest (under 3\%, as against an average of $15 \%$ ), constitute the only residential area in Cali that possibly influences the answers: given the same phenotypes, the probability of selfreporting as having black skin is only half as high(32).

To summarize, to the extent that self-characterization of phenotypes is indicative of the construction of a black identity in Cali(33), its close link with the phenotypic characterization made by the interviewer suggests that this identity operates primarily with reference to the racial categories used by the population, to the divisions and boundaries these categories underpin, and to the stigma or, conversely, positive connotation that they convey in various contexts. Next come geographic origins, age, and socio-occupational category, but the pattern of those determinations differs sharply from that of the neo-ethnic identity in the Pacific region. Unlike the influence over the latter of local social and political dynamics, whether as causes or consequences of Law 70, no single principle governs the process of construction of urban "black" identity. This appears to be both more complex and more endogenous. Rather than a form of transfer to the city of a hypothetical ethnic and territorial identity derived from the region of origin, we make the hypothesis that it reflects the experience of citizens who are subject to various types of discrimination or at least aware of this risk, faced with unequal access to urban resources (housing, employment, education, health services, etc.).

\section{Conclusion}

The argument of this article can be summed up in a single sentence: There exists a need in Colombia, particularly in the urban settings, for a phenotypic categorization of the population (based on external categorization and self-perception), and for a clarification of its use for analysing the socio-racial segregation and discrimination that affects the African Colombian population, of which a majority is now urban. The first results of the survey show that the black and mulatto population in Cali is not homogeneous with respect to socio-demographic characteristics, particu-

\footnotetext{
(32) Verifying this would require testing the interactions between age, socio-occupational category and place of origin; the limits imposed by the sample size are reached here.

(33) It must be admitted that this hypothesis has not been completely demonstrated. To support or qualify it would require methods that offer stricter control of the various contextual effects, which as we have seen exert a powerful influence on self-perception. Contextual or multilevel analyses are potentially valuable for this.
} 
larly because of its high mobility and its diversity as regards both geographical origin and historical and economic context. For any subsequent analysis to be effective, it needs to build largely on the description of that mobility, with detailed exploration of its economic, social and cultural aspects in their spatial and temporal dimensions. The geographical origins of the migration flows, the residential itineraries in and out of Cali, as well as the conditions of access to the different types of economic and social capital, are determining factors in the strategies for insertion and adaptation in urban environments, and must be examined for the interactions between them. When interpreting the differentials observed, careful consideration must be given to the interplay between spatial, historical, social and racial factors. The aim is not therefore to consider the racial factor independently of the others; but we believe that we have demonstrated that this information, as produced by the survey, provides valuable elements for an analysis of discrimination and of the factors of exposure to racism. Does this also hold for the impact of urban policies, particularly in their social aspects, on the reality and perception of segregation in its multiple forms?

The question is important because, on the one hand, as mentioned earlier, a democratic debate about the place of blacks in the multicultural society has been going on in Colombia since 1993. On the other hand, the armed conflict and the extremely tense social and political situation in the country necessarily impinge on the black question, and are already a source of very strong tensions and polarization. In her recent article on political mobilization in the Nariño Pacific coast, O. Hoffmann concluded:

"In general, the categories developed by 'the river people' over the identity issue are often subtler and more flexible than those adopted by the intellectuals and leaders of the black movement (see for instance the combinations of phenotypic, residential, kinship and social practice criteria used for defining who is member of a territory, and consequently 'black'). Rather than a contradiction, this difference of points of view reflects currently insurmountable external constraints. The leadership can reason only within frameworks constructed elsewhere (in the capital, or in political circles), which concentrate attention on specificities, thus favouring an 'essentialist' interpretation of the social, cultural, economic and political realities of the populations involved. This contrasts with the position at the grassroots, where daily experience of co-existence tends to favour flexibility and negotiation." (Hoffmann, 2000, p. 50).

It is also relevant to ask how the debate in Colombia is influenced by the history, present situation and analytical accounts of racial segregation in the United States. The forms of exclusion experienced by the black minority there, particularly the ghetto archetype, though by no means comparable to conditions in Colombia, are constantly used as references by the different actors involved-journalists, politicians, activists in associations or in black community movements, young people in the city's Agua Blanca neighbourhood, rap musicians, etc. As we have seen, the survey provides no quantitative evidence at all for the existence of a racial ghetto in Cali, contrary to what some journalists have written, whose sen- 
sationalism has helped to create an image of the Agua Blanca neighbourhood as a black township, with the associated stereotypes. On the other hand, economic and social marginalization through poverty, unemployment, restricted access to infrastructure and services, as well as delinquency, are undeniably real in this part of the city. As L. Wacquant writes, drawing a clear distinction between the situations in France and in the United States with a sentence that perfectly applies in the Cali context:

"Discussion should therefore focus not on the ghetto but, in order of importance, on access to employment, education, housing, or in other words, to the means for effective citizenship." (Wacquant, 1992, p. 28).

It seems to us that citizenship and equal opportunities are indeed the issues that must be placed at the heart of the current debate on the place of blacks in Colombian society, because they have been historically - and in many respects still are - a dominated category of the population.

\section{REFERENCES}

Agier M., Hoffmann O., 1999, "Les terres des communautés noires dans le Pacifique colombien. Interprétations de la loi et stratégies d'acteurs", Problèmes d'Amérique latine, No. 32, Paris, La documentation française, pp. 17-42.

Agier M., Barbary O., Hoffmann O., Quitin P., Ramirez H.F., Urrea F., 2000, Final report on the CIDSE/IRD project in COLCIENCIAS, CIDSE, Cali, $88 \mathrm{p}$.

Agudelo C., 1998, Cambio constitucional y organización política de las poblaciones negras en Colombia. Proyecto Movilidad, urbanización e identidades de las poblaciones afrocolombianas, Documento de trabajo, No. 26, Universidad del Valle, Cali, 28 p.

Agudelo C., Hoffmann O.,Rivas N., 1999, Hacer política en el Pacífico sur, algunas aproximaciones, Documentos de trabajo del CIDSE, No. 39, Proyecto CIDSE-IRD, Cali, 83 p.

Arocha J., 1992, "Los negros y la nueva constitución colombiana de 1991", América Negra, No. 3, Pontificia Universidad Javeriana, Bogotá.

Barbary O., 1998, Cuestionario de la encuesta "Movilidad, urbanización e identidades de las poblaciones afrocolombianas", Universidad del Valle, Cali, $32 \mathrm{p}$.

Barbary O., Ramirez H.F., 1997, Tabulación del censo de población y vivienda de 1993 en Cali, Informe de etapa de la parte cuantitativa ${ }^{\circ} 1$, Proyecto Movilidad, urbanización e identidades de las poblaciones afrocolombianas, vol. 1, Universidad del Valle, Cali, 752 p.

Barbary O., Bruyneel S., Ramirez H.F., Urrea F., 1999, Afrocolombianos en el área metropolitana de Cali, estudios sociodemográficos, Documentos de trabajo del CIDSE, No. 38, Proyecto CIDSE-IRD, Cali, 98 p.

Blum A., 1998, "Comment décrire les immigrés? À propos de quelques recherches sur l'immigration", Population, 53(3), pp. 569-588.

De Friedemann N., 1998, "Le rôle de l'Afri - $D$ et des Noirs dans la construction de l'Amérique", in La chaîne et le lien. Une visıon de la traite négrière, Paris, UNESCO, pp. 383-394.

Desrosières A., 1993, La politique des grands nombres, histoire de la raison statistique, La Découverte, Paris, $438 \mathrm{p}$.

Dureau F., Barbary O., Goueset V., Pissoat O., 2002, Recompositions urbaines en Amérique Latine : une lecture structurée à partir du cas colombien (forthcoming, Paris, AnthroposIRD).

Groupe DE RÉFleXion SUR L'APPRoche biographiQue (eds. Antoine Ph., Bonvalet C., Courgeau D., Dureau F., Lelièvre E.), 1999, Biographies d'enquêtes. Bilan de 14 collectes biographiques, Paris, INED-PUF, (coll. Méthodes et savoirs, No. 3), 336 p.

Hoffmann O., 2000, "Jeux de parole et de mémoire autour des mobilisations identitaires (Colombie)", Autrepart, No. 14 : Logiques identitaires, logiques territoriales, Paris, L'aube-IRD, pp. 33-51. 
Hoffmann O., Pissoat O., 1999, “Aproximación a la diferenciación espacial en el Pacifico, un ensayo metodológico”, Documentos de trabajo del CIDSE, No. 42, Proyecto CIDSEIRD, Cali, 45 p. and appendices.

Hutchens R., 2001, "Numerical measures of segregation: desirable properties and their implications", Mathematical Social Sciences, No. 42, New York, pp. 13-29.

Le Bras H., 1998, Le démon des origines. Démographie et extrême droite, Paris, Éditions de l'Aube, $261 \mathrm{p}$.

Massey D.S., DEnTON N.A., 1988, “The dimensions of residential segregation”, Social Forces, No. 67, pp. 281-315.

Massey D.S., White M.J., Phua V.C., 1996, “The dimensions of segregation revisited”, Sociological Methods and Research, 25(2), pp. 172-206.

Simon P., 1997, "La statistique des origines, race et ethnicité dans les recensements aux ÉtatsUnis, Canada et Grande-Bretagne", Sociétés contemporaines, No. 26, pp. 11-44.

Simon P., 1999, "Nationality and origins in French statistics. Ambiguous categories", Population: An English Selection, 11, pp. 193-220.

Tribalat M. (with the participation of P. Simon and B. Riandey), 1996, De l'immigration à l'assimilation, enquête sur les populations d'origine étrangère en France, La Découverte/ INED, Paris, $302 \mathrm{p}$.

URREA F., 1997, "Dinámica sociodemográfica, mercado laboral y pobreza urbana en Cali durante las décadas de los años del 80 y 90", Coyuntura Social, No. 17, Bogotá, pp. 105-164.

Urrea F., Ortiz C.H., 1999, Patrones sociodemográficos, pobreza y mercado laboral en Cali, a working paper for the World Bank, Cali, $66 \mathrm{p}$.

Vanin A., AgIER M., Hurtado T., Quintín P., 1999, Imágenes de las 'culturas negras' del Pacífico colombiano, Documentos de trabajo del CIDSE, No. 40, Proyecto CIDSE-IRD, Cali, $63 \mathrm{p}$.

WACQUANT L., 1992, "Pour en finir avec le mythe des cités ghetto", Les annales de la recherche urbaine, No. 54, pp. 20-30.

WADE P., 1997, Gente negra, nación mestiza. Dinámicas de las identidades raciales en Colombia, Eds. Universidad de Antioquía, ICAN, Siglo del Hombre, Uniandes, Bogotá. 
Barbary Olivier-- Measurement and Practices of Social and Racial Segmentation in Cali. A Survey of African Colombian Households

In Colombia as in other Latin American countries, the last decade has brought recognition of ethnic and cultural diversity in the official discourse and in the Constitution. This change is the result, among other factors, of a mobilization by civil society and political and scientific circles over the condition of minorities and the segregation and discrimination processes affecting them. The south-west region and its metropolis Cali, as major seats of the African Colombian and, to a lesser extent, the indigenous population, are at the heart of the issue. Building on a survey conducted in 1998 in Cali, this article raises the problem of measuring and analysing racial segmentation and its links to spatial and social mobility. In the context of a society with a high level of $\equiv 1$ mixing, what is advocated here is the use of phenotypic categories to capture the compl $\square$ ations between social and ethnic inequality, and to suggest a preliminary diagnosis of segregation and discrimination in Cali, building on the residential distribution and socio-economic conditions for insertion in the city, but also using the respondents' perception. The survey also reveals the strong heterogeneity of this population, due largely to its diversified geographic origins and the highly varied historical and economic circumstances of its migration. Lastly, through logistic regressions on the answers to ethnic and phenotypic questions, the article explores the determinants of the African Colombian identity assertion movement that has recently emerged in the country, and suggests a new approach to the question of the black population's place in the Colombian mixed-race society.

\section{BARBARY Olivier.- Indicadores y realidad de la segmentación socio-racial in Cali. Una encuesta sobre los hogares afro-colombianos}

En Colombia, como en otros países de América Latina, en los últimos diez años se llegó al reconocimiento progresivo, y finalmente constitucional, de la diversidad étnica y de la multiculturalidad. Esta evolución es el resultado, entre otros factores, de la movilización de la sociedad civil y de los medios políticos y científicos en torno a la condición de diversas poblaciones en situación de 'minorías' demográficas, y de los procesos de segregación y de discriminación que las afectan. La región sudoeste del país y su metrópoli Cali, como importantes focos de población afrocolombiana y, en menor grado, indígena, están en el centro de esta problemática. Partiendo de una encuesta realizada en 1998 en dicha ciudad, el articulo plantea el problema de la medición y análisis de la segmentación racial y de sus vínculos con la movilidad espacial y social. En el contexto de una sociedad altamente mestizada, se defiende aquí el uso de categorías fenotípicas del lenguaje común para medir y comprender las relaciones complejas entre desigualdades sociales y raciales, y plantear, desde las percepciones y opiniones de los encuestados, un primer diagnóstico sobre la segregación y la discriminación en Cali. Los primeros resultados ponen en evidencia la fuerte heterogeneidad de la población, ligada a la diversidad de sus orígenes geográficos y a la variedad de los contextos históricos y económicos de la migración. Finalmente, analizando con modelos de regresión logística las respuestas a las preguntas de auto percepción étnica y fenotípica, el articulo aborda los determinantes de la emergencia reciente de la afirmación de una identidad afrocolombiana, un proceso que plantea de manera renovada la cuestión del lugar de la población negra en la sociedad mestiza colombiana.

Olivier BARBARY, Institut de Recherche pour le Développement, Centre d'Analyse et de Mathématique sociales, EHESS, 2 rue de la Charité, 13002 Marseille, France, e-mail: obarbary@ehess.cnrs-mrs.fr 